\title{
Antibiotic residues in pasteurized and unpasteurized milk marketed in southwest of Paraná, Brazil
}

\author{
Valfredo Schlemper $^{1^{*}}$ Ana Paula Sachet ${ }^{1}$
} 'Departamento de Medicina Veterinária, Universidade Federal da Fronteira Sul (UFFS), Campus Realeza, 85770-000, Realeza, PR, Brasil.
E-mail: valfredo.schlemper@uffs.edu.br. "Corresponding author.

\begin{abstract}
The treatment of dairy cattle with antibiotics may lead to milk contamination by drugs residues, which represents risks to human health. This study aimed to investigate the presence of antibiotic residues in milk, produced and marketed in Capanema microregion, Paraná, Brazil, through the analysis of pasteurized milk samples from different brands consumed by the local population and unpasteurized

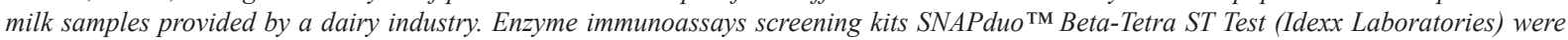
used, which verified the presence of $\beta$-lactam and tetracyclic drugs residues, as well as enzyme immunoassays screening kits Charm ROSA Test (Charm Sciences), which established the presence of quinolones and sulfonamides groups. Positive samples were reported for the four different classes of drugs, demonstrating failures in the inspection and monitoring of the sanitary and chemistry quality of the milk. Results obtained will form the basis to building a database about the quality of milk produced and marketed in the region, as well as the use of these materials to build up an initial theoretical framework for the development of research in animal health and public policies focused on the milk producers and dairy industry, to improve the quality of the milk produced.

Key words: antibiotic, milk quality, public health, food safety, pasteurization.
\end{abstract}

Resíduos de antibióticos no leite pasteurizado e não pasteurizado comercializados no sudoeste do Paraná, Brasil

RESUMO: O tratamento do rebanho leiteiro com antibióticos pode levar a contaminação do leite por resíduos de medicamentos, o que representa riscos para a saúde humana. Este trabalho procurou investigar a presença de resíduos de antibióticos no leite, produzido e comercializado na microrregião de Capanema, Paraná, Brasil, através da análise de amostras de leite pasteurizado de diferentes marcas consumidas pela população local, além de amostras de leite não pasteurizado, fornecidas por um laticínio da região. Testes de triagem imunoenzimáticos SNAPduo ${ }^{\mathrm{TM}}$ Beta-Tetra ST Test (Idexx Laboratories) foram utilizados para verificar a presença de resíduos de antibióticos das classes $\beta$-lactâmicos e tetracíclicos, bem como os kits imunoenzimáticos Charm ROSA Test (Charm Sciences) que verificaram a presença dos grupos de antibióticos quinolonas e sulfonamidas nas amostras. Foram encontradas amostras positivas para as quatro classes de antibióticos pesquisadas, demonstrando falhas na inspeção e no monitoramento da qualidade química e sanitária do leite. Os resultados obtidos servirão de base para a construção de um banco de dados sobre a qualidade do leite produzido e comercializado na região, bem como o uso dessas informações para o desenvolvimento de pesquisas em saúde animal e politicas públicas voltadas para os produtores de leite e laticínios da região, buscando a melhoria da qualidade do leite produzido.

Palavras-chave: antibiótico, qualidade do leite, saúde pública, segurança alimentar, pasteurização.

\section{INTRODUCTION}

Over the last years, the presence of chemical residues, especially antibiotics and pesticides in food of animal origin has become a public health issue. The world population is commonly exposed to drug residues through microdoses present in food, resulting in a variety of serious health effects such as hypersensitivity and anaphylactic shock, especially in children, pregnant women and the elderly, anemia, diarrhea and kidney problems, imbalance of intestinal flora and teratogenicity, besides ototoxicity and problems in fetal bone development (NASCIMENTO et al, 2001; MARTIN, 2011; TROMBETE et al, 2014). Moreover, the indiscriminate use of these substances promotes antimicrobial resistance, which can lead to antibiotic therapy unsuccessfully (WHITE \& MCDERMOTT, 2001). 
Furthermore, these chemical residues are resistant to conventional heat treatment used for manufacturing pasteurized milk $\left(72^{\circ} \mathrm{C}\right)$, so industrial technologies are considered ineffective to eliminate these drugs residues (TIAN et al., 2016).

In addition, fermented products like cheese and yogurt have its processes closely affected by the presence of antibiotic residues in raw material, as these usually inhibit partially or totally the growth of dairy cultures (starter cultures), damaging the sensory and structural characteristics of those milk products (FONSECA et al, 2009).

The presence of antibiotic residues in milk may occur for many reasons, including the indiscriminate use of drugs for treatment of herd diseases, by not disposing contaminated milk and due to prolonged or excessive dosages of drugs (TROMBETE et al, 2014). Milk contamination by antimicrobials residues can still be possibly originating from the intentional addition, performed in order to inhibit undesirable bacterial growth, thus covering the deficiency in the hygienic quality of milk (PONTES NETTO et al, 2005). Therefore, monitoring the use of these substances is essential to ensure food security and to provide adequate guidance of the drugs used by farmers and milk producers (TOLENTINO et al, 2005). Consequently, it is necessary to implement preventive measures to notice the presence of these chemical residues in milk consumed by the general population.

This study searched to verify the possible presence of antibiotic residues in pasteurized and unpasteurized milk, produced and marketed in the microregion of Capanema, State of Paraná, Brazil, through qualitative screening methods for detection of four different groups of drugs, $\beta$-lactams, tetracyclines, quinolones and sulfonamides, to map the status of the chemical milk quality in respect of contamination by antibiotic residues.

\section{MATERIALS AND METHODS}

\section{$\beta$-lactam and tetracyclic research}

A collection of 100 pasteurized milk samples of 13 different brands collected from many different commercial establishments in the city of Realeza, state of Paraná, during the period from April 2015 to August 2015 were analyzed. Choice of brands was based on information provided by the supermarkets, according to the milk consumption by the population. Samples were collected weekly for a period of five months, all with full packaging and within the expiration date. They were stored and kept in refrigeration temperature (between $4^{\circ} \mathrm{C}$ and $10^{\circ} \mathrm{C}$ ) until the moment of analysis.

To detection of $\beta$-lactam and tetracyclic antibiotic groups, the SNAPduo ${ }^{\mathrm{TM}}$ Beta-Tetra ST Tests (Idexx Laboratories) were used according to manufacturer's recommendations. These tests allow detection residues of tetracycline, oxytetracycline, chlortetracycline, penicillin G, amoxicillin, ampicillin, ceftiofur and cefapirin and other antimicrobial group of tetracyclines and $\beta$-lactams on the same device, by immunoenzymatic reaction. These methods are considered as qualitative tests, with high specificity and sensitivity in detecting different antibiotics residues in milk and are also effective, fast and recognized by Brazilian law.

\section{Quinolones and sulfonamides research}

To detection of quinolones and sulfonamides residues, 99 samples of unpasteurized milk donated by a dairy industry were analyzed. Samples were collected during October 2015, and were stored in a refrigerator at temperature between $4^{\circ} \mathrm{C}$ and $10^{\circ} \mathrm{C}$, as explained in the previous method, and analyzed at the same week. Samples were randomly selected by the staff responsible for the milk quality of the dairy and available in individual containers properly identified with the dairy farmer number. Commercial kits of Charm ROSA Test (Charm Sciences Inc.) were used, which have the capacity to identify the presence of 15 different sulfonamides and 11 quinolones, through immunoenzymatic reaction. These are also regarded as qualitative, fast, effective and easy tests to apply, but do not allow the quantification of antimicrobial concentrations tested.

\section{Data analysis}

Results were analyzed considering the frequency of antibiotic residues appearance in the samples, according to antibiotic class, singly or in combination with a group of drugs. The organization of the data was performed in population sampling charts, and tables showing values in percentage or numeric real value, created in GraphPad Prism 6. A descriptive statistical analysis of the records was also performed, and results were prearranged into two groups, negative and positive, for the $\beta$-lactam and tetracyclic research. Within the positive samples, the results were set orderly in three different groups for the SNAP test results: positive for both classes of antibiotics, positive for $\beta$-lactams and negative for tetracyclic and positive for tetracyclic and negative for $\beta$-lactams. To the ROSA Charm test results, only two distinct groups were ordered, positive results for quinolones and positive for sulfonamides. 


\section{RESULTS AND DISCUSSION}

As the results of screening tests, 100 samples of pasteurized milk were examined, and 17 were positive for one of the two groups, $\beta$-lactam or tetracyclic, indicating a contamination rate of $17 \%$ of the pasteurized milk samples. Among the positive results, we can highlight that those 17 positive samples, 11 were positive for $\beta$-lactam antibiotic residues and the other 6 samples were positive for both of classes, $\beta$-lactam and tetracyclic (Table 1).

The use of pasteurized milk samples to investigate antibiotic residues is recommended by different researchers, as there is a concern in determining the risks that the population has been constantly exposed. It is proven that antimicrobial drugs molecules are not destroyed by pasteurization method (BRASIL, 2017). None of the technologies are able to eliminate drugs residues from contaminated food, either the molecule in its totality or as a metabolite form, evidencing the presence of such substances in the final product.

The number of positive samples is considered high when compared with other previous studies conducted in several Brazilian States (Rio de Janeiro, Goiás, Minas Gerais, Rio Grande do Sul and São Paulo), where 100 samples of UHT milk were analyzed and only 4 of them were considered positive, showing a $4 \%$ of contamination rate (FONSECA et al., 2009).

According to NOVAES et al (2017), false negative results can occur on the screening tests possibly as an interaction with some substances applied for preserving milk or for those molecules presents in some detergents used for cleaning the milking machine. Nevertheless, this is a serious public health problem, which shows possible failures in both the production process, related to the work done by producers and veterinarians in the field, and in the industrialization process, which is responsibility of the dairy and public agencies, in addition to other establishments that process and industrialize the raw material.

To explain the high rate of positive samples reported in this study, could be considered the fact that the survey was conducted on winter season in south Brazil, between April to August, a period characterized by lower temperatures and higher amount of rainfall, which increases the incidence of disease in dairy cattle, evidencing the improved exposure of the animals to antibiotic treatment, with consequent contamination of the milk by residues of these drugs.

Besides, when we analyze the use of medications for treatment of animal's diseases it is important to look at the variation of the drugs grace period. For example, a farmer who needs to medicate a lactating cow to treat a clinical mastitis and must reject that milk for a determined period, presumably after the time indicated in the package leaflet, the milk could return to be used for consumption. However, it is not happening in many cases where, according to reports of the farmers, as a preventive measure, they send milk samples for the dairy to check if there are still antibiotic residues in that milk, and in some cases the sample continues to show positive results for much longer period than the drug manufacturer had previously established. This is a serious problem for the industry because, in addition to the dairy waste supplementary costs and expenses in carrying out the screening tests used, the industry also loses in processing raw material, transportation and logistics in general.

However, this situation should be well evaluated because dairy farmers are taking large losses when disposing of milk, and they find no other alternative but to treat the sick animal, following the principles of animal welfare. Likewise, milk disposal on the farm is in many cases considered incorrect, where in most situations, farmers use that milk as feed for calves and other animals, as well as in circumstances where it is dumped open-air, which can cause soil contamination and consequently accumulation of these chemical residues in the environment.

Regarding to the research of quinolones and sulfonamides, among 99 samples were analyzed, being four of them positive for quinolone group, and six samples showed positive results for sulfonamides residues (Table 1). According to results, the frequency of positive samples for both classes of antimicrobials, quinolones and sulfonamides, was considered low when compared to the previous test. However, these two groups of antimicrobial drugs are overlooked by the Brazilian legislation, which does not receive any kind of control by the industry, so if its presence in milk occurs, certainly this contaminated food would go through the process of industrialization and consequently to the supermarket shelves.

To obtain comparative indices, literature references of other studies conducted in Brazil were required, but no data were located about milk analysis for these classes of antibiotics. In other countries, it is common to research these residues in unpasteurized milk, as these drugs are commonly used in animal therapy. For instance, in a study conducted in Korea using microbial inhibition tests and confirmation of the results by liquid chromatography, 269 milk samples were analyzed, with 239 of bovine milk and 30 of goat milk, and of these, 15 (5.57\%) were positive for sulfonamides and 3 (1.11\%) positive for quinolones (CHUNG et al, 2009). 
Table 1 - Results of the qualitative tests applied in the research.

\begin{tabular}{|c|c|c|c|c|}
\hline Method & Antibiotic group & $\mathrm{N}^{\circ}$ of samples & Positive & Negative \\
\hline SNAPduo $^{\mathrm{TM}}$ ST Test & ß-lactam and tetracyclic & $100^{*}$ & 17 & 83 \\
\hline Charm ROSA Test & Quinolone & $99^{* *}$ & 4 & 95 \\
\hline Charm ROSA Test & Sulfonamide & $99^{* *}$ & 6 & 93 \\
\hline
\end{tabular}

"Pasteurized milk samples; ${ }^{* *}$ Unpasteurized milk samples.

Additionally, in an investigation conducted in New York using enzyme immunoassays like those applied in this study, the authors reported that of the 34 samples tested, 28 were positive for antibiotic residues, and of these, $7.1 \%$ were to sulfonamides, being this a higher percentage if compared to the data reported in this research (PEREIRA et al, 2014). Also, authors from a study guided in Macedonia reported positive values above in the 497 milk samples for residues of these antibiotics, where $18.4 \%$ of the samples tested were positive for sulfonamides and $6.8 \%$ to quinolones (STOJKOVIC et al, 2011).

\section{CONCLUSION}

Considering the results obtained, it is concluded that the rates of positive samples for antibiotic residues of $\beta$-lactams and tetracyclic in pasteurized milk marketed in the microregion of Capanema - PR are high, thereby demonstrating deficiencies in monitoring of these chemical residues which are still the most antimicrobials used in the treatment of diseases affecting the dairy herd. Compared to the results obtained for quinolones and sulfonamides residues present in unpasteurized milk, the numbers were lower than the other surveys conducted in other countries, but serves as a comparative parameter for analysis of the reality of this region, regarding the use of these antimicrobials in animal therapy. However, despite low numbers, these cannot be ignored by the authorities because they are not routinely monitored in dairy industry, and its indiscriminate use can bring future losses with regard to the resistance of microorganisms often exposed to these substances and the population that is constantly subject to microdoses intake of these drugs through food.

\section{ACKNOWLEDGEMENTS}

This research was supported with funds from the Universidade Federal da Fronteira Sul (UFFS) through the scientific initiation scholarship (Edital number 281/UFFS/2015) and laboratory structure. Authors would like to thank the Idexx
Laboratories (Idexx Brasil Laboratórios LTDA), by donating 100 kits SNAPduo ${ }^{\text {TM }}$ Beta-Tetra ST Test, as well as the Charm Sciences INC (Hexis Cientifica), by the donation of 200 kits ROSA Charm Tests and the LATCO dairy, present in the City of Realeza, State of Paraná, Brazil, which provided the samples of raw milk used is this study.

\section{REFERENCES}

Brasil. Ministério da Agricultura, Pecuária e Abastecimento. Decreto no 9.013 de 29 de março de 2017, que regulamenta a Lei no 1.283 , de 18 de dezembro de 1950, e a Lei no 7.889, de 23 de novembro de 1989, que dispõem sobre a Inspeção Industrial e Sanitária de Produtos de Origem Animal. Available from: <http:/www.planalto.gov.br/ccivil_03/ ato2015-2018/2017/decreto/D9013.htm>. Online. Accessed: July 28, $201 \overline{7}$.

CHUNG, H. H. et al. Analysis of sulfonamide and quinolone antibiotic residues in Korean milk using microbial assays and high performance liquid chromatography. Food Chemistry, v. 113, p. 297-301, 2009. Available from: <http://www.sciencedirect.com/science/article/pii/ S0308814608008455>. Online. Accessed: July 28, 2017.

FONSECA, G. P. et al. Antibiotic residues in Brazilian UHT milk: a screening study. Ciência e Tecnologia de Alimentos, v. 29, p. 451-453, 2009. Available from: <http://www.scielo.br/ scielo. php?script=sci_arttext\&pid=S0101-20612009000200035>. Online. Accessed: July 28, 2017.

MARTIN, J. G. P. Antimicrobial residues in milk - A review. Segurança Alimentar e Nutricional, v. 18, p. 80-87, 2011. Available from: $<$ http://periodicos.sbu. unicamp.br/ojs/index.php/ san/article/view/8634680/2599>. Online. Accessed: July 28, 2017.

NASCIMENTO, G. G. F. et al. The occurrence of antibiotic residues in milk in commercial establishments in the City of piracicaba, São Paulo, Brazil. Revista de Nutrição, v. 14, p. 119-124, 2001. Available from: <http://www. scielo.br/pdf/rn/v14n2/7560.pdf $>$. Online. Accessed: July 28, 2017.

NOVAES, S. F. et al. Residues of veterinary drugs in milk in Brazil. Ciência Rural, v. 47, n. 8, p. 1 - 7, 2017. Available from: <http:// www.scileo.br/br/pdf/cr/v47n8/1678-4596-cr-47-08-e20170215. pdf $>$. Online. Accessed: July 28, 2017.

PEREIRA, R. V. et al. Multiresidue screening of milk withheld for sale at dairy farms in central New York State. Journal of Dairy Science, v. 97, p. 1513-1519, 2014. Available from: <https://www.ncbi.nlm.nih. gov/pubmed/24440252>. Online. Accessed: July 28, 2017.

PONTES NETTO, D. et al. Levantamento dos principais fármacos utilizados no rebanho leiteiro do estado do Paraná. Acta 
Scientiarum. Animal Sciences, v. 27, p. 145-151, 2005. Available from: <http://periodicos.uem.br/ojs/index.php/ActaSciAnimSci/ article/view/ 1260/ 692>. Online. Accessed: July 28, 2017.

STOJKOVIC, E. D. et al. Screening of veterinary drug residues in milk from individual farms in Macedonia. Macedonian Veterinary Review, v. 34, p. 5-13, 2011. Available from: <http:// agris.fao.org/agris-search/search.do?recordID=MK2013100040>. Online. Accessed: July 28, 2017

TIAN, L. et al., Effect of thermal treatments on the degradation of antibiotic residues in food. Journal of Critical Reviews in food Science and Nutrition, v. 57, p. 3760-3770, 2016. Available from: $<$ http://www.tandfonline.com/doi/full/10408398.2016.1164119>. Online. Accessed: Aug. 07, 2017.
TOLENTINO, R. G. et al. Determination of the presence of 10 antimicrobial residues in Mexican pasteurized milk. Interciencia, v. 30, p. 291-294, 2005. Available from: $<$ http://www.scielo.org.ve/scielo.php?script=sci_arttext\&pi $\mathrm{d}=\mathrm{S} 0378-18442005000500009>$. Online. Accessed: July 28, 2017.

TROMBETE, F. M. et al. Residuos de antibióticos en la leche comercializada en Brasil: una revisión de los estudios publicados en los últimos años. Revista Chilena de Nutrición, v. 41, p. 191-197, 2014. Online. Available from: $<\mathrm{http}: / / \mathrm{www}$. scielo.cl/scielo.php?script=sci arttext\&pid=S0717-75182014000200010>. Accessed: Aug. 07, 2017.

WHITE, D. G.; MCDERMOTT, P. F. Emergence and Transfer of Antibacterial Resistance. Journal of Dairy Science, v. 84, p. 151-155, 2001. Available from: <http://www.journalofdairyscience.org/article/ S0022-0302(01)70209-3/pdf>. Online. Accessed: Aug. 07, 2017. 